\title{
Knowledge Management untuk Menciptakan Daya Saing Bisnis Keluarga Pada Pengelolaan Bisnis Kuliner di Kota Palembang
}

\author{
Trisninawati \\ Universitas Bina Darma \\ Email: trisninawati@binadarma.ac.id \\ Dina Mellita \\ Universitas Bina Darma \\ Email:dinamellita@binadarma.ac.id
}

\begin{abstract}
The culinary business in the city of Palembang is one of the family businesses that has been passed down for generations, the culinary business in recent years can create growth opportunities for employment and increase the ability of human resources. Management of many family businesses is controlled and operated by one member or several families and many family businesses have non-family members as employees. This study aims to determine the role of knowledge management in creating human resources who are ready to compete in the culinary industry in the city of Palembang. by analyzing the factors that must be considered such as the next generation development factors, information technology, and business development. This research uses a qualitative approach through in-depth interviews and direct observation. The results of this study indicate that the culinary business in the family business is still carried out traditionally the application of technology is still limited so the need for the role of knowledge management in order to be able to identify knowledge can realize competitiveness and sustainability as a benchmark for the success of the family business especially the culinary business in the city of Palembang
\end{abstract}

Keywords: Knowledge Management, human resources, family business

\begin{abstract}
Abstrak
Bisnis kuliner di kota Palembang merupakan salah satu bisnis keluarga yang sudah turun temurun, bisnis kuliner tersebut dalam beberapa tahun ini dapat menciptakan peluang pertumbuhan bagi lapangan kerja dan peningkatan kemampuan sumber daya manusia. Manajemen bisnis keluarga banyak dikendalikan dan dioperasikan oleh satu anggota atau beberapa keluarga dan banyak bisnis keluarga memiliki anggota non keluarga sebagai karyawan. Penelitian ini bertujuan untuk mengetahui peran knowledge management dalam menciptakan sumber daya manusia yang siap untuk berdaya saing pada industri kuliner di kota Palembang. dengan menganalisis faktor- faktor yang harus diperhatikan seperti faktor pengembangan generasi penerus, teknologi informasi,dan pengembangan usaha. Penelitian ini menggunakan pendekatan kualitatif melalui wawancara mendalam dan observasi langsung. Hasil penelitian ini menunjukkan bahwa bisnis kuliner dalam bisnis keluarga masih dilakukan tradisional penerapan teknologi masih terbatas sehingga perlu adanya peran knowledge management agar mampu mengidentifikasi pengetahuan dapat mewujudkan daya saing dan berkelanjutan sebagai tolak ukur keberhasilan bisnis keluarga khususnya bisnis kuliner di kota Palembang.
\end{abstract}

Kata kunci : Pengetahuan Manajemen, Sumber Daya Manusia, Bisnis Keluarga 


\section{Pendahuluan}

Organisasi bisnis dalam menghadapi lingkungan global yang kompetitif banyak disebabkan oleh faktor-faktor mikro dan makro, untuk mengatasi persaingan ini pentingnya sumberdaya manusia di organisasi perlu diperhatikan hal ini disebabkan sumberdaya manusia merupakan salah satu modal utama di organisasi. Pada akhirnya menjadi satu-satunya sumber daya hidup di organisasi, memberikan inovasi dan membawa pengetahuan baru untuk mendapatkan keunggulan kompetitif,karyawan perusahaan bertanggung jawab atas modal manusia. Memasuki diera pengetahuan tahun 1990, pengembangan di berbagai bidang mulai dilakukan dengan pengetahuan. Menurut Organization for Economic Cooperation and Development (OECD), ekonomi berbasis pengetahuan seperti produksi, penggunaan distribusi pengetahuan sebagai penggerak utama pertumbuhan, penciptaan kekayaan, dan pekerjaan untuk semua industri (AlHawamdeh, 2003).

Saat ini manajemen pengetahuan menjadi salah satu penggerak organisasi yang kompetitif dan berdaya saing. Berkembang pesatnya perubahan di era globalisasi ini perusahaan keluarga sebagai salah satu penggerak ekonomi harus cepat tanggap dimana perubahan-perubahan ekonomi berkembang di bawah pengaruh pengetahuan yang semakin menguat seiring dengan inovasi dan kreatifitas. Dalam ekonomi berbasis pengetahuan banyak dipahami kondisi aktivitas komersial seperti organisasi, kelembagaan, sosial dalam meningkatkan efisiensi penyerapan pengetahuan dan inovasi, selain itu untuk meningkatkan daya saing ekonomi dan proses belajar dan mendidik entitas dalam kondisi mereka untuk keberlangsungan hidup organisasi (Chojnicki, Czyż, 2006). Salah satunya upaya penguatan bisnis keluarga, dalam hal ini upaya penguatan UMKM bisnis keluarga sebagai penggerak ekonomi untuk dapat berdaya saing.

Menciptakan bisnis keluarga yang berdaya saing tersebut dapat dicapai salah satunya dengan menerapkan konsep perbaikan berkelanjutan serta mendorong bisnis keluarga untuk berkembang dengan menciptakan inovasi pada produknya. Salah satu cara yang memberikan solusi bagi bisnis keluarga adalah dengan knowledge management. Demikian juga yang dihadapi pelaku usaha bisnis keluarga seperti industri kuliner yang ditekuni oleh beberapa pemilik usaha kuliner di Kota Palembang, berdasarkan wawancara yang mendalam dari beberapa usaha bisnis keluarga di kota Palembang masih ada beberapa usaha bisnis keluarga pengelolaan usaha kuliner masih berjalan dengan konsep usaha yang masih minim dengan ilmu pengetahuan terbatas terutama di bidang sumberdaya manusia sehingga masih mengalami tingkat pendapatan yang tidak stabil, keinginnan berpindah karyawan masih tinggi sehingga tidak tercapai target yang diharapkan oleh pemilik usaha, sehingga menyebabkan tidak berkembangnya usaha. Berdasarkan uraian diatas penelitian ini bertujuan untuk mengetahui peran knowledge management dalam menciptakan sumber daya manusia yang siap untuk berdaya saing pada industri kuliner di kota Palembang. 


\section{Literature Review}

\subsection{Knowledge Management}

Knowledge Management dalam metode pengelolaan perusahaan terdiri dari mengumpulkan, memproses, menyebarkan dan menggunakan pengetahuan untuk mencapai tujuan organisasi (Słownik,2005). Berkenaan dengan aktivitas komersial dan menetapkan tujuan organisasi tersebut mengelola pengetahuan sebagai sumber kunci sumber keunggulan persaingan, knowledge management juga dapat digunakan untuk memperbaiki produk atau proses (prosedur), dapat menjadi kegiatan inti setiap organisasi.

Knowledge management mencakup semua tindakan yang mengarah pada akses pengetahuan untuk semua anggota organisasi. Sehingga memberikan manfaat pada proses pengambilan keputusan menjadi lebih pendek, memberi kemungkinan reaksi langsung terhadap kondisi yang berubah secara dinamis (Evans, 2007). Semakin pentingnya knowledge management dalam organisasi ditentukan oleh banyak faktor. Salah satunya adalah variabilitas kondisi yang dipahami secara luas di sekitar organisasi karena perubahan sering tidak dapat diprediksi, sulit untuk menentukan hambatan apa yang mungkin terjadi di masa depan dan pengetahuan apa yang dibutuhkan untuk mengatasinya. Banyak masalah yang terjadi menunjukkan kekurangan pengetahuan dan kebutuhan untuk memperoleh pengetahuan baru (Figurska, 2007. Knowledge management dalam organisasi juga berawal dari semakin cepat tingkat devaluasi pengetahuan. Seperti pengetahuan, motivasi, dan keterampilan manusia tunduk pada depresiasi dan dapat bertahan dalam kondisi yang berubah secara dinamis seseorang harus terus memperluas pengetahuan dan keterampilan dan mempraktekkannya.

Kemampuan mengelola pengetahuan sangat terkait dengan kemampuan menerapkan perubahan dan inovasi. Inovasi dalam hal ini aplikasi pengetahuan yang tidak konvensional dan sekaligus merupakan sumber untuk perubahan lebih lanjut, yang memerlukan keterampilan baru (Bochniarz, Gugała, 2005) dalam Firgusa (2009) Knowledge management yang tepat dapat mempengaruhi pembentukan kualitas sumber daya manusia. Berbagi dan diseminasi pengetahuan sangat penting bagi pertumbuhan kreativitas dan inovasi di kalangan pekerja, yang tercermin dalam tindakan yang dilakukan oleh mereka.

\subsection{Manajemen Sumber Daya Manusia}

Konsep HRM memandang sumber daya manusia sebagai aset perusahaan dan sumber daya saingnya. Tujuan manajemen sumber daya manusia menyiapkan karyawan yang berkualitas bagi perusahaan dengan memperhatikan pendidikan dan pelatihan yang dapat meningkatkan kemampuan keterampilan dan kompetensinya untuk memenuhi kebutuhan organisasi dan memastikan pencapaian tujuannya (Aliya, 2019). Sumber daya manusia dapat dipertimbangkan secara kuantitatif (jumlah karyawan dalam sebuah organisasi) dan aspek kualitatif, di mana sumber daya tersebut dianggap sebagai karakteristik dan sifat totalistik yang tercakup di dalamnya, yang memungkinkan peran yang berbeda dalam organisasi (Pocztowski, 2007). Terkait terhadap Knowledge management pendekatan ini terhadap fungsi personil dalam organisasi yang ditandai dengan mengambil perspektif strategis, keterlibatan manajemen lini, mengenali karakter 
unik sumber daya manusia, memastikan pertumbuhan nilai karyawan berdasarkan perkembangan merek, keterlibatan penuh para karyawan dalam realisasi tugas (Słownik, 2005). Pengetahuan, bakat, kesehatan, sikap, nilai dan motivasi karyawan merupakan salah satu elemen terpenting yang dimiliki oleh karyawan. Sehingga organisasi akan memiliki kekuatan dalam menjalankan bisnisnya.

Lipka (2005) mengemukakan HRM dalam konteks knowledge management memberikan kualitas SDM yang optimal bagi organisasi, tindakan ini sangat strategis karena membutuhkan waktu lama untuk membangun kualitas "(Lipka, 2005). Lipka (2005) memasukkan knowledge management seperti kebijakan rekrutmen, investasi ke karyawan, memotivasi, membentuk kepercayaan, menciptakan loyalitas, realokasi karyawan dan restrukturisasi pekerjaan, hingga tindakan yang dilakukan harus dikoordinasikan baik dari segi waktu dan konten.Mengetahui orang dan pengetahuan individu dengan baik dapat mengetahui masalah dan proses bisnis yang paling signifikan dan harus menjadi bagian fungsi HRM karena hanya melalui HRM mereka dapat menciptakan nilai bagi organisasi (Bochniarz, Gugała, 2005) dalam Firgusa (2009).

\section{Metode Penelitian}

Penelitian dilakukan dengan menggunakan desain kualitatif. Dalam penelitian ini melakukan wawancara mendalam terhadap informan. Informan dalam penelitian ini adalah manajer UMKM dalam hal ini khususnya usaha keluarga yaitu baik pemilik UMKM ataupun seseorang yang dipercaya untuk mengelola UMKM tersebut.Wawancara mendalam dilakukan untuk dapat memberikan informasi mengenai penerapan knowledge management diharapkan mampu mendapatkan informasi langsung dari respondent mengenai pengetahuan dan pemahaman knowledge management tersebut yang dikemukakan oleh Edvardsson dan Durst (2013) bahwa usaha kecil bisa mendapatkan keuntungan dalam mengimplementasikan knowledge management dengan pencapaian seperti kenaikan penjualan dan penurunan kerugian.

Seperti: - Pengembangan dari generasi penerus

- Hubungan karyawan

- pengembangan usaha

- teknologi informasi

Penelitian ini menggunakan pendekatan kualitatif dengan menggunakan interview mendalam dan observasi langsung pada pemilik dan karyawan pada UMKM kuliner di Kota Palembang. Diawali peneliti mengajukan pertanyaan penelitian dan menjawabnya secara induktif. Jawaban dari pertanyaan ini akan menghasilkan suatu simpulan. Dari proses analisa data yang berasal dari wawancara ini beserta analisanya akan didapat perbedaan, persamaan dan pola yang menjadi dasar untk pembuktian dari pernyataan atau kesimpulan dari temuan yang diambil.

\section{Objek Penelitian}

Penelitian ini dilakukan pada Usaha Mikro Kecil dan Menengah di Kota Palembang dengan mengambil 12 UMKM dari bisnis keluarga yang terbagi dengan jenis kuliner, yaitu: 
- Kuliner Pempek Palembang

- Kuliner Mie Celor

- Kuliner tekwan dan model

- Kerupuk Palembang

\section{Hasil dan Pembahasan}

Berikut ini penjelasan langsung tentang hasil wawancara yang dapat disimpulkan dan temuan-temuan lainnya tentang penerapan Knowledge Management.

\begin{tabular}{|c|c|c|c|}
\hline Jenis kuliner & Aktifitas & Hasil & kesimpulan \\
\hline Mie Celor & $\begin{array}{l}\text { Pengembangan } \\
\text { generasi penerus } \\
\text { dan hubungan } \\
\text { karyawan } \\
\text {,penngembagan } \\
\text { usaha dan } \\
\text { teknologi informasi }\end{array}$ & $\begin{array}{l}\text { Bisnis turun menurun yang } \\
\text { sudah memasuki generasi } \\
\text { ke dua dalam usaha } \\
\text { keluarga. Tenaga kerja } \\
\text { yang dimiliki dengan } \\
\text { merekruit keluarga sendiri } \\
\text { dan mengikat hubungan } \\
\text { kekeluargaan. Teknologi } \\
\text { secara umum mereka } \\
\text { menemukan bahwa } \\
\text { kemampuan } \\
\text { danmenerapkan dan } \\
\text { menggunakan teknologi } \\
\text { pada UMKM harus } \\
\text { diperkuat. }\end{array}$ & $\begin{array}{l}\text { Perkembangan } \\
\text { sumberdaya } \\
\text { manusia dalam } \\
\text { usaha kuliner ini. } \\
\text { Melakukan } \\
\text { perbedaan terhadap } \\
\text { generasi kedua } \\
\text { dengan menjalankan } \\
\text { teknologi informasi } \\
\text { seperti konsep } \\
\text { pemasaran yang } \\
\text { dibantu dengan } \\
\text { teknologi informasi } \\
\text { dalam membangun } \\
\text { promosi hal ini } \\
\text { menunjukkan } \\
\text { adanya perubahan } \\
\text { Knowledge. } \\
\text { Tantangan yang } \\
\text { cukup besar adalah } \\
\text { bermunculan disatu } \\
\text { kawasan yang sama } \\
\text { yaitu jenis kuliner } \\
\text { yang sama sebagai } \\
\text { pesaing dari kuliner } \\
\text { mie celor. Sehingga } \\
\text { generasi kedua harus } \\
\text { melakukan } \\
\text { pemikiran yang luas } \\
\text { dalam hal } \\
\text { pengembangan } \\
\text { usaha kuliner yang } \\
\text { didasarkan } \\
\text { knowledge generasi } \\
\text { kedua sabagai salah } \\
\text { satu pengembangan }\end{array}$ \\
\hline
\end{tabular}




\begin{tabular}{|c|c|c|c|}
\hline & & & $\begin{array}{l}\text { sumberdaya } \\
\text { manusia untuk } \\
\text { mengetahui } \\
\text { keberhasilan usaha } \\
\text { bisnis keluarga }\end{array}$ \\
\hline Kerupuk & $\begin{array}{l}\text { Pengembangan } \\
\text { generasi penerus } \\
\text { dan hubungan } \\
\text { karyawan } \\
\text {,pengembagan } \\
\text { usaha dan } \\
\text { teknologi informasi }\end{array}$ & $\begin{array}{l}\text { Pengembangan } \\
\text { sumberdaya manusia dari } \\
\text { jenis usaha kerupuk ini } \\
\text { mengalami peningkatan } \\
\text { yang signifikan selama } 10 \\
\text { tahun yang disebabkan } \\
\text { oleh perubahan dengan } \\
\text { menciptakan inovasi } \\
\text { produk. Bisnis keluarga } \\
\text { ini dengan penarikan } \\
\text { karyawan melalui rekruit } \\
\text { dari keluarga sendiri dan } \\
\text { rekan sejawat di wilayah } \\
\text { terdekat dengan usaha } \\
\text { kuliner. }\end{array}$ & $\begin{array}{l}\text { Perkembangan } \\
\text { usaha kuliner ini } \\
\text { mengalami } \\
\text { perubahan yang } \\
\text { diperlukan adalah } \\
\text { ilmu pengetahuan } \\
\text { dan ketrampilan. } \\
\text { Tantangan di era } \\
\text { saat ini bisnis } \\
\text { keluarga adalah } \\
\text { perubahan generasi } \\
\text { yang dituntut oleh } \\
\text { ilmu pengetahuan } \\
\text { dan ketrampilan. }\end{array}$ \\
\hline $\begin{array}{l}\text { Kuliner tekwan } \\
\text { dan model }\end{array}$ & $\begin{array}{l}\text { Pengembangan } \\
\text { generasi penerus } \\
\text { dan hubungan } \\
\text { karyawan } \\
\text {,pengembagan } \\
\text { usaha dan } \\
\text { teknologi informasi }\end{array}$ & $\begin{array}{l}\text { Pengembangan } \\
\text { sumberdaya manusia dari } \\
\text { jenis usaha kuliner ini } \\
\text { mengalami peningkatan } \\
\text { yang signifikan selama } 10 \\
\text { tahun yang disebabkan } \\
\text { oleh perubahan dengan } \\
\text { menciptakan inovasi } \\
\text { produk. Bisnis keluarga } \\
\text { ini dengan penarikan } \\
\text { karyawan melalui rekruit } \\
\text { dari keluarga sendiri dan } \\
\text { rekan sejawat di wilayah } \\
\text { terdekat dengan usaha } \\
\text { kuliner. }\end{array}$ & $\begin{array}{l}\text { Perkembangan } \\
\text { usaha kuliner ini } \\
\text { mengalami } \\
\text { perubahan yang } \\
\text { diperlukan adalah } \\
\text { ilmu pengetahuan } \\
\text { dan ketrampilan. } \\
\text { Tantangan di era } \\
\text { saat ini bisnis } \\
\text { keluarga adalah } \\
\text { perubahan generasi } \\
\text { yang dituntut oleh } \\
\text { ilmu pengetahuan } \\
\text { dan ketrampilan. }\end{array}$ \\
\hline Kuliner pempek & $\begin{array}{l}\text { Pengembangan } \\
\text { generasi penerus } \\
\text { dan hubungan } \\
\text { karyawan } \\
\text {,pengembagan } \\
\text { usaha dan } \\
\text { teknologi informasi }\end{array}$ & $\begin{array}{l}\text { Pengembangan } \\
\text { sumberdaya manusia dari } \\
\text { jenis usaha kuliner ini } \\
\text { mengalami peningkatan } \\
\text { yang signifikan selama } 10 \\
\text { tahun yang disebabkan } \\
\text { oleh perubahan dengan } \\
\text { menciptakan inovasi } \\
\text { produk. Bisnis keluarga } \\
\text { ini telah berjalan oleh }\end{array}$ & $\begin{array}{l}\text { Perkembangan } \\
\text { usaha kuliner ini } \\
\text { mengalami } \\
\text { perubahan yang } \\
\text { diperlukan adalah } \\
\text { ilmu pengetahuan } \\
\text { dan ketrampilan. } \\
\text { Tantangan di era } \\
\text { saat ini bisnis } \\
\text { keluarga adalah } \\
\end{array}$ \\
\hline
\end{tabular}




\begin{tabular}{|l|l|l|}
\hline & generasi kedua yang & perubahan generasi \\
& memiliki banyak & yang dituntut oleh \\
perbedaan. Hal ini adanya & ilmu pengetahuan \\
perubahan konsep usaha & dan ketrampilan. \\
dan inovasi produk. & \\
& penarikan karyawan & \\
& melalui rekruit dari \\
& keluarga sendiri dan rekan & \\
& sejawat di wilayah & \\
& terdekat dengan usaha & \\
& kuliner. & \\
\hline
\end{tabular}

Penerapan knowledge management pada UMKM bisnis keluarga yang paling penting adalah berkaitan pelaksanaan operasional, seperti pengelolaan keuangan, keunikan produk,dan pelayanan kepada konsumen, selain itu loyalitas dan integritas merupakan pembentukan pengetahuan utama melalui pengalaman kerja. Pada UMKM dalam objek penelitian ini pengelolaan operasional usaha masih bersifat tradisional dan kekeluargaan dimana pemilik keluarga memainkan peran penting terutama dalam pengelolaan opersional, sehingga adanya knowledge management ini dalam pengambilan keputusan utama pemilik usaha harus mampu mengelola pengetahuannya untuk dapat mentrasfer ilmu pengetahuan tersebut kepada karyawannya dalam proses pembaharuan sehingga keputusan dalam bisnis dapat didelegasikan. Pentingnya keterlibatan keluarga menggambarkan pengaruh anggota keluarga pemilik dan bisnis keluarga pemilik terhadap pengambilan keputusan manajerial dan kegiatan operasional di bidang fungional bisnis hal ini didukung data Indonesia survey report family business 2014 sebesar 60\%. Masing-masing UMKM dapat mentransfer pengetahuan sebagai proses pembaharuan informasi dan pengetahuan karyawan sangatlah penting melalui training internal baik secara vertikal maupun horizontal. Dengan demikian pemilik usaha harus terbuka untuk membagi semua ilmu yang dimilikinya kepada semua karyawan agar usaha yang dijalankan mampu berdaya saing dan karyawan memiliki ketrampilan yang berkompeten. Dengan demikian dapat dipahami bahwa bisnis keluarga keterlibatan keluarga dalam keputusan manajerial dan kegiatan opersional memberikan kontribusi bahwa keluarga memiliki tugas dan tugas tersebut untuk mencapai tujuan bisnis, kontribusi tersebut dapat dilihat lebih jauh dalam waktu yang singkat serta pengambilan keputusan tingkat fungsional dan operasional, sehingga semua karyawan akan termotivasi untuk berprestasi dengan baik.

Peningkatan signifikansi pengetahuan menyebabkan banyak perubahan dalam organisasi seperti perubahan bentuk pekerjaan, membatasi volume pekerjaan, fleksibilitas peserta pasar kerja yang lebih baik, perubahan hubungan kerja, dll. (Scenariusze,2008) dalam Fergusa (2009) pentingnya karyawan bagi organisasi serta pendekatan atasan terhadap karyawan, merupakan sebagai sumber daya layak diinvestasikan untuk keberhasilan organisasi maupun kinerja karyawan itu agar mendapatkan hasil yang maksimal dan mampu bersaing (Figurska, 2008).

Salah satu kondisi dasar knowledge management yang efektif adalah membangun budaya pengetahuan, di mana layanan personal memainkan peran kunci. Karyawan dan 
manajer sumber daya manusia harus bersama-sama mendefinisikan seperti apa budaya berorientasi pengetahuan dan bagaimana hal itu harus dicapai, dan kemudian menginformasikan kepada para karyawannya dengan menggunakan berbagai bentuk komunikasi, tidak langsung dan langsung, formal dan informal. Dalam organisasi berorientasi pengetahuan karyawan mengkoordinasikan pekerjaan mereka biasanya melalui komunikasi informal. Dalam kerangka kebijakan spesifik kepegawaian tentang sikap yang dapat diterima dan tidak dapat diterima harus disediakan. Prinsip-prinsip tersebut harus tercermin dalam memilih, memotivasi dan mengembangkan karyawan (Bochniarz, Gugała, 2005)

Menggunakan teori Resource based view dalam penelitian ini merupakan salah satu solusi bagi usaha bisnis keluarga dapat berdaya saing dengan jenis usaha yang lain. Resource based view dapat menjelaskan bagaimana sumber daya internal dari suatu perusahaan dapat meraih keunggulan kompetitif yang berkelanjutan, faktor internal memiliki potensi bagi perusahaan untuk meraih keunggulan kompetitif.Menurut Barney(2001), untuk meraih keunggulan kompetitif, sumber daya perusahaan harus memiliki empat kriteria yaitu: langka, tidak dapat ditiru,bernilaidan tak tergantikan. Dalam bisnis keluarga usaha kuliner pendekatan resource based view untuk meraih keunggulan kompetitif melalui identifikasi sumber daya perusahaan yang heterogen,pendekatan ini bertujuan untuk mengelompokkan sumber-sumber daya strategis perusahaan yang paling berpotensi untuk menciptakan keunggulan kompetitif dan berdaya saing. Dengan demikian usaha kuliner bisnis keluarga dalam penelitian ini harus memperhatikan kriteria dalam menciptaka daya saing yaitu langka,tidak dapat ditiru bernilai dan tak tergantikan.

\section{Simpulan}

Penelitian ini mendapatkan gambaran mengenai pelaksanaan knowledge management pada UMKM bisnis keluarga dalam keberhasilan usahanya dan mengidentifikasi faktor-faktor yang mempengaruhi keberhasilan usahanya. UMKM bisnis keluarga masih melakukan secara tradisional dan konvensional. Pemilik UMKM sebagai sentral ilmu pengetahuan di tempat aktifitas pekerjaannya melakukan transfer ilmu kepada karyawannya,namun masih memiliki keterbatasan dalam mengidentifikasi pengetahuan yang dapat membantu mewujudkan rencana strategis seperti keterbatasan waktu, rendahnya kemampuan karyawan untuk menerima ilmu-ilmu yang terbaru yang disesuaikan dengan perubahan dinamika perekonomian dan demografi. 


\section{Daftar Pustaka}

Aliya, S., \& Tobari, T. (2019) Pengaruh Pendidikan dan Pelatihan Terhadap Produktivitas Kerja Karyawan Bagian Produksi Pada PT. Semen Baturaja (Persero) Tbk Palembang. Jurnal Manajemen, Kepemimpinan, dan Supervisi Pendidikan, Volume 4, No.1, 97-103

Barney (2001). Resouce based theories of competitive advantage: a ten year retrospective the resource based view. Journal of Management. 27. 643-650

Evans, Ch. (2005). Zarządzanie wiedzą. Warszawa. PWE. 2005. ISBN 83-208-1575-4

Edvandsson dan Durst, S (2013). The benefits of Knowledge Management in Small and Medium Size Enterprises. Procedia Social and Behavioural Sciences No.81.

Figurska (2009) I. Knowledge management obstacles in theory and practice. [In]: Manaņment l’udského potenciálu v podniku. M. Blańková, J. Suchomel (red.). N̦ilina. N̦ilinská univerzita. 2009. ISBN 978-80554-0013-6

Kuruppuge Ravindra Hewa, Gregar Ales. 2017. Family Involvement, Employee Engagement and Employee Performance in Enterprising Family Firms. Acta Universitatis Agriculturae et Silviculturae Mendelianae Brunensis, 65(5): 1695-1707.

Lipka, A. (2005).W stronę kwalitologii zasobów ludzkich. Warszawa. Wydawnictwo Difin. ISBN 83-7251-551-4

Pocztowski, A ( 2007) . Zarządzanie zasobami ludzkimi. Warszawa. PWE. 2007. ISBN 83208-1662-9

Stownik zarzadzania kadrami. T. Listwan (red.). Warszawa. Wydawnictwo C. H. Beck. 2005. ISBN 83-7387-405-4.

Villalonga, B and Amit, R. 2006. How do family ownership. control and management firm value?. Journal of Financial Economics,80(1),385-417

Indonesia Report Family Business Survey 2014. www.pwc.com 